\title{
An LC-MS Method for the Analysis of Some Organic Acids in Tobacco Leaf, Snus, and Wet Snuff *
}

by

Serban C. Moldoveanu, Thomas Poole, and Wayne A. Scott

R.J. Reynolds Tobacco Co., Winston-Salem, NC, USA

\section{SUMMARY}

The present study describes the analysis of several organic acids in tobacco and smokeless tobacco products using a liquid chromatography (LC) method with mass spectrometric (MS) detection (LC-MS). Prior to the application of the LC-MS method, a qualitative analysis for the identification of the organic acids in tobacco and oral tobacco products was performed. The qualitative method used direct silylation of the plant material followed by GC-MS separation and detection. For the acids' quantitation, a novel LC-MS method has been developed and validated. The acids of interest for quantitation were the following: acetic, citric, fumaric, glyceric, lactic, maleic, malic, oxalic, pyroglutamic, pyruvic, quinic, and trihydroxybutanoic. The LC separation was performed on a Synergy $4 \mathrm{u}$ Hydro-RP column $250 \times 4.6 \mathrm{~mm}$, with an aqueous mobile phase containing $5 \%$ methanol and $0.15 \%$ formic acid. The LCMS method has the advantage versus LC methods with other detection types (refractive index, UV absorption at low UV range, or conductivity) of being capable of positive identification of the analytes based on their specific ions, and of having significantly better sensitivity. Unfortunately, the LC-MS method was not generating good results for oxalic acid and acetic acid also expected to be present in some samples of tobacco or tobacco products. The study describes the advantages and disadvantages of the LC-MS method for the analysis of organic acids in tobacco and smokeless tobacco products. [Beitr. Tabakforsch. Int. 28 (2018) 30-41]
KEY WORDS: Organic acids, hydroxy acids, tobacco, oral tobacco products

\section{ZUSAMMENFASSUNG}

Die vorliegende Studie beschreibt die Analyse verschiedener organischer Säuren in Tabak und rauchlosen Tabakprodukten unter Verwendung einer Flüssigchromatographie (LC)-Methode mit massenspektrometrischer (MS) Detektion (LC-MS). Vor Anwendung der LC-MS-Methode wurde eine qualitative Analyse zur Identifizierung der organischen Säuren in Tabak und in oralen Tabakprodukten durchgeführt. Die qualitative Methode verwendete die direkte Silylierung des Pflanzenmaterials sowie GC-MS-Trennung und Detektion. Für die Quantifizierung der Säuren wurde eine neuartige LC-MS-Methode entwickelt und validiert. Die für die Quantifizierung interessanten Säuren waren: Essigsäure, Zitronensäure, Fumarsäure, Glycerinsäure, Milchsäure, Maleinsäure, Apfelsäure, Oxalsäure, Pyroglutaminsäure, Brenztraubensäure, Chinasäure und Trihydroxybutansäure. Die LC-Trennung wurde auf einer Synergi $4 \mathrm{u}$ Hydro-RP Säule $250 \times 4,6 \mathrm{~mm}$ durchgeführt, mit einer wässrigen mobilen Phase mit 5\% Methanol und 0,15\% Ameisensäure. Die LC-MS-Methode hat gegenüber LCMethoden mit anderen Detektionsarten (Brechungsindex, UV-Absorption im niedrigen UV-Bereich oder Leitfähigkeit) den Vorteil, dass (ausgehend von ihren spezifischen Ionen) eine positive Identifizierung der Analyten und eine signifikant bessere Sensitivität möglich ist. Leider brachte 
die LC-MS-Methode keine guten Ergebnisse für Oxalsäure und Essigsäure hervor, deren Vorkommen auch in einigen Proben von Tabak und Tabakerzeugnissen erwartet wird. In der Studie werden die Vorteile und Nachteile der LC-MSMethode für die Analyse organischer Säuren in Tabak und rauchfreien Tabakprodukten beschrieben. [Beitr. Tabakforsch. Int. 28 (2018) 30-41]

\section{RESUME}

Le présent article décrit l'analyse de divers acides organiques présents dans le tabac et les produits de tabac sans fumée grâce à la méthode (LC-MS) de détection par chromatographie en phase liquide (LC) associée à la spectrométrie de masse (MS). Avant de procéder par la méthode LC-MS, une analyse qualitative fut menée afin d'identifier les acides organiques présents dans le tabac et les produits de tabac à usage oral. L'étude qualitative reposa sur une silylation directe de la matière végétale suivie d'une détection et séparation par GC-MS. Pour la quantification des acides, une méthode novatrice par LCMS fut mise au point et validée. Les acides retenus pour la quantification furent les suivants: Acide acétique, citrique, fumarique, glycérique, lactique, maléique, malique, oxalique, pyroglutamique, pyruvique, quinique et trihydroxybutanoïque. La séparation par chromatographie en phase liquide fut accomplie sur une colonne Synergy $4 \mathrm{u}$ Hydro$\mathrm{RP}$ de $250 \times 4,6 \mathrm{~mm}$, avec une phase mobile aqueuse contenant $5 \%$ de méthanol et $0,15 \%$ d'acide formique. Comparativement aux méthodes LC recourant à d'autres types de détection (par indice de réfraction, par absorption des UV dans la longueur d'ondes inférieure ou par conductivité), la méthode LC-MS présente l'avantage de pouvoir proposer une identification positive des analytes sur la base de leurs ions spécifiques et d'afficher une sensibilité nettement améliorée. Malheureusement, la méthode LC-MS ne livra pas de bons résultats pour l'acide oxalique et l'acide acétique dont la présence était attendue dans certains échantillons de tabac ou produits de tabac. L'article expose les avantages et les inconvénients de la méthode LC-MS en vue de l'analyse des acides organiques présents dans le tabac et les produits de tabac sans fumée. [Beitr. Tabakforsch. Int. 28 (2018) 30-41]

\section{INTRODUCTION}

Plant materials, including tobacco, frequently contain organic acids such as acetic, citric, fumaric, glyceric, lactic, maleic, malic, oxalic, pyroglutamic, pyruvic, quinic, and trihydroxybutanoic (two isomers). The acids in tobacco and tobacco products play an important role for the sensorial properties of the tobacco products (smoke quality, quality of oral tobacco products). The common acids from tobacco may contain, besides the - $\mathrm{COOH}$ group (or groups), other polar groups such as $-\mathrm{OH}$ or $=\mathrm{O}$. For this reason, they have high polarities, with low octanol/water distribution coefficients $D_{o w}$. For example, at $\mathrm{pH}=2.9$, for quinic acid log $D_{o w}=-2.45$, for lactic acid $D_{o w}=-0.72$, for malic acid $D_{o w}=-1.26$, for citric acid $D_{o w}=-1.08$, and for pyruvic acid $D_{o w}=-1.24$. Qualitative identification of such acids can be performed using GC-MS only after derivatization because of their low volatility and the presence of the polar groups. Silylation, for example, is a good derivatization procedure changing the acids in their trimethylsilyl (TMS) derivatives and allowing positive identifications based on searches to the available mass-spectral libraries (see e.g., (1)). Methylation has also been used for acid derivatization and GC separation (2). However, the quantitation following derivatization is typically affected by larger errors as compared to direct analysis, and sample preparation is more elaborate. For these reasons, quantitation using highperformance liquid chromatography (HPLC) technique is typically preferred for these acids. Common HPLC techniques used for the quantitation of these acids involve ion exclusion (IEC) separation (3-9). Besides that, hydrophilic interaction (HILIC) $(10,11)$, and reversed phase (RPHPLC) $(12,13)$ were sometimes utilized in acids separation. Each separation technique has advantages and disadvantages. Both IEC and HILIC separations typically have broader peaks as compared to RP-HPLC separations (14), and for this reason the peak resolution in IEC and HILIC is not as good as in RP-HPLC. In RP-HPLC, the necessity to have a high water content in the mobile phase in order to achieve good separation of compounds with low $D_{o w}$ values requires the use of columns resilient to high water content in the mobile phase. Also, it is advantageous for the separation of these very polar compounds to have RP columns that display polar interactions in addition to the main hydrophobic interactions. Among these are the columns with embedded polar groups or polar end-capped (15).

The detection of some organic acids that contain chromophore groups (e.g., double bonds) can be done with good sensitivity using UV absorption. However, many acids do not have such groups and detection using conductivity, refractive index (RI), or UV absorption at low wavelength (e.g., 210-220 nm) must be utilized. In such cases, the sensitivity of the detection is not very high. Also, UV at low wavelengths, RI, and conductivity are not selective detection techniques. When such detections are utilized, the identification of the acids can be done only based on their retention time. In complex matrices such as a plant extract, interferences are likely, in particular with RI detection. The advantages of MS detection are obvious regarding selectivity and in most cases sensitivity. For this reason, MS detection is a preferred one, compared to other detection types $(6,12)$. However, MS detection, besides its higher price, has its own limitation related to restrictions regarding the composition of the mobile phase (e.g., sulfuric acid typically used as eluent in IEC is not compatible with MS detection, and a suppressor for $\mathrm{H}_{2} \mathrm{SO}_{4}$ elimination is necessary before detection) and lack of linearity of the detector response in a wide concentration range.

Present study utilizes a common GC-MS analytical technique for the identification of organic acids in tobacco leaf, snus and wet snuff, based on direct silylation of plant material. For quantitation, a novel LC-MS method has been developed and validated. The method provides good results for most acids expected to be present in the samples, except for oxalic and acetic acid. 


\section{MATERIALS AND METHODS}

\subsection{Materials}

Several organic acids including acetic, citric, fumaric, lactic, maleic, malic, oxalic, pyroglutamic, pyruvic, quinic, and trihydroxybutanoic as well as phosphoric acid, monopotassium phosphate, tert-butylhydroquinone, dimethylformamide (DMF), and methanol (CHROMASOLV ${ }^{\circledR}$ Plus) were purchased from Sigma/Aldrich (St. Louis, MO, USA). Citric acid-2,2,4,4- $\mathrm{d}_{4}$ and sodium L-lactate-3,3,3- $\mathrm{d}_{3}$ were purchased from $\mathrm{C} / \mathrm{D} / \mathrm{N}$ Isotopes Inc. (Point-Claire, Quebec, Canada). N,O-bis(trimethylsilyl)-trifluoroacetamide (BSTFA) with $1 \%$ trimethylchlorosilane (TMCS) was obtained from UCT (Bristol, PA, USA).

Water $18.2 \mathrm{~m} \Omega / \mathrm{cm}$ was obtained from a Barnsted Nanopure unit (Thermo Scientific Rockford, IL, USA). For the filtration of plant extracts, $0.45 \mathrm{~mm}$ PVDF filters were used (Whatman Autovial, GE Healthcare, Little Chalfort, UK). Scintillation vials of $20 \mathrm{~mL}$ and GC vials of $2 \mathrm{~mL}$ with screw top caps with septa were also utilized.

\subsection{Instrumentation}

A wrist action shaker (Burrell Co., Pittsburgh, PA, USA) was used for the extraction of the samples. A freeze dryer FreeZone 4.5 from Labconco (Kansas City, MO, USA) was used for drying snus and wet snuff samples. The moisture was measured using a HR83 Halogen Moisture Analyzer from Mettler Toledo (Greifensee, Switzerland). The GCMS analysis was performed on a GC-MS 7890-5975 from Agilent (Agilent Technologies Inc., Wilmington, DE, USA). The GC separation was performed on a Zebron ZB$5 \mathrm{~ms}$ chromatographic column from Phenomenex (Torrance, CA, USA). The HPLC separation with MS detection was performed on an Agilent 1200 HPLC binary system that consisted of a binary pump, an autosampler with cooling capability, and a column thermostatted compartment. The HPLC chromatographic separation was achieved on Synergy Hydro-RP column $250 \times 4.6 \mathrm{~mm}$ with $4 \mu \mathrm{m}$ particles from Phenomenex. A Fortis $\mathrm{H}_{2} \mathrm{O} 100 \times 3.0 \mathrm{~mm}$ with $1.7 \mu \mathrm{m}$ particles column (Fortis Technologies, Cheshire, UK) was also evaluated but not utilized in sample analysis. The MS system was an API-5000 triple quadrupole mass spectrometer (AB Sciex, Framingham, MA, USA). The LC-MS/MS was controlled using Analyst 1.6.2 software, and the peak integration was performed with MultiQuant 2.1.1 software. The same type of instrumentation was used for the LC-UV analysis, except that the LC system also included a variable wavelength UV detector.

\subsection{Preliminary sample preparation}

Tobacco samples were finely ground without any other processing (the wet snuff was used as is). For the qualitative analysis (using derivatization), the snus and the wet snuff samples were freeze-dried. For quantitative analysis all samples were analyzed without drying. Tobacco moisture/oven volatiles were separately measured on the samples using the halogen moisture analyzer. Since the moisture analysis procedure may also include some volatiles (16), it was selected to indicate the organic acid levels as obtained for the sample "as is", and to report the moistures separately.

\subsection{GC-MS analysis}

For the GC-MS analysis, samples of $50 \mathrm{mg}$ of freeze dried plant material were weighed (with $0.1 \mathrm{mg}$ precision) in 2-mL GC vials. The samples were silylated directly, without using a preliminary extraction. For this purpose, $400 \mu \mathrm{L}$ of DMF that contains an internal standard was added to each vial containing the sample. The internal standard was tert-butylhydroquinone at a concentration of $400 \mu \mathrm{g} / \mathrm{mL}$. The silylation (formation of TMS derivatives) was done adding to each sample $800 \mu \mathrm{L}$ BSTFA with $1 \%$ TMCS. The vials were kept at $78^{\circ} \mathrm{C}$ (in a heating block) for $30 \mathrm{~min}$, and subsequently allowed to cool at room temperature for another $30 \mathrm{~min}$. After cooling the solution from each vial was filtered through $0.45 \mu \mathrm{m}$ PVDF filters and analyzed. The GC-MS conditions for the analysis are indicated in Table 1.

Peak identification in the total ion chromatograms (TIC) was performed using data processing capability of the GCMS instrument (Chemstation F.01.01.2317) and the mass spectral libraries NIST14 and Wiley275.

Table 1. GC-MS operating parameters.

\begin{tabular}{lcc|c}
\hline Parameter & Description & Parameter & Description \\
\hline Initial oven temperature & $50{ }^{\circ} \mathrm{C}$ & Flow mode & Constant flow \\
Initial time & $0.5 \mathrm{~min}$ & Flow rate & $1.0 \mathrm{~mL} / \mathrm{min}$ \\
Oven ramp rate & $3{ }^{\circ} \mathrm{C} / \mathrm{mm}$ & Nominal initial pressure \\
Oven final first ramp & $200{ }^{\circ} \mathrm{C}$ & Split ratio & $30: 1$ \\
Final time first ramp & $0 \mathrm{~min}$ & Split flow & $30 \mathrm{~mL} / \mathrm{min}$. \\
Oven ramp rate & $4{ }^{\circ} \mathrm{C} / \mathrm{mm}$ & Outlet pressure \\
Oven final temperature & $300^{\circ} \mathrm{C}$ & Transfer line heater \\
Final time & $10 \mathrm{~min}$ & lon source temperature \\
Total run time & $85 \mathrm{~min}$ & Quadrupole temperature \\
Inlet temperature & $300{ }^{\circ} \mathrm{C}$ & Resulting EM voltage \\
Inlet mode & $\mathrm{Split}$ & MSD solvent delay \\
Injection volume & $1.0 \mathrm{~mL}$ & MSD acquisition mode \\
Carrier gas & Helium & Mass range \\
\hline
\end{tabular}


Tobacco silylation followed by GC-MS analysis has been frequently used for qualitative analysis of plant materials (see e.g., (17-19)).

\subsection{LC-MS separation and detection}

For the LC-MS analysis, $50 \mathrm{mg}$ sample were weighed (with $0.1 \mathrm{mg}$ precision) in $20 \mathrm{~mL}$ vials. To each of the weighed samples, $15 \mathrm{~mL}$ water containing $0.1 \%$ formic acid was added. The samples were extracted on a wrist action shaker for $30 \mathrm{~min}$, and filtered through $0.45-\mu \mathrm{m}$ PVDF filters. The samples were further diluted and $200 \mu \mathrm{L}$ extract was placed in a 2-mL screw top cap vial. To the vial were added $800 \mu \mathrm{L}$ water containing $0.1 \%$ formic acid and $20 \mu \mathrm{L}$ solution containing two internal standards (see quantitation procedure). The extraction was not performed directly with $75 \mathrm{~mL}$ solvent to reduce the solvent use and to be able to use the same initial extract for the LC-UV analysis. The samples were stable for at least two weeks when stored in a chilled autosampler or a refrigerator at $5{ }^{\circ} \mathrm{C}$. Repeated analyses of the same samples within this interval of time indicated an $\mathrm{RSD} \%$ around $5 \%$.

The HPLC separation was performed on the Synergy Hydro-RP column in isocratic conditions with a mobile phase containing $95 \%$ water and $5 \%$ methanol, to which was added $1.5 \mathrm{~mL}$ formic acid per $1 \mathrm{~L}$ solution. The use of a larger column (4.6 $\mathrm{mm}$ i.d.) with a larger mass of stationary phase allowed the injection of relatively concentrated samples (with concentration at about $20-40 \mu \mathrm{g} / \mathrm{mL}$ for some individual acids). The flow rate of the mobile phase was $0.6 \mathrm{~mL} / \mathrm{min}$, and the injection volume was $1.0 \mu \mathrm{L}$. The column temperature was kept at $20^{\circ} \mathrm{C}$. The HPLC used a needle wash with $50 / 50$ methanol water.

The detection of compounds in the eluate was performed using negative electrospray ionization (ESI) in MRM mode. However, the same ion was used for both precursor and product ion. All the parameters were optimized for generating the highest sensitivity of detection.

These parameters included: collision gas $(\mathrm{CAD})=0$, curtain gas
$(\mathrm{CUR})=10 \mathrm{~mL} / \mathrm{min}$, ion spray voltage (IS) $=-4000 \mathrm{~V}$, temperature $(\mathrm{TEM})=600{ }^{\circ} \mathrm{C}$, ion source gas $1(\mathrm{GS} 1)=$ $45 \mathrm{~mL} / \mathrm{min}$, ion source gas $2(\mathrm{GS} 2)=35 \mathrm{~mL} / \mathrm{min}$, declustering potential $(\mathrm{DE})=-10 \mathrm{~V}$, entrance potential $(\mathrm{EP})=-5 \mathrm{~V}$. The acquisition time for each ion was $200 \mathrm{~ms}$. The specific ions used for detection and the resulting retention times for each analyte are indicated in Table 2.

Table 2. Ions used for detection and elution retention time.

\begin{tabular}{l|c|c}
\hline Compound & Ion for Q1 and Q3 & $\begin{array}{c}\text { Retention time } \\
\text { (min) }\end{array}$ \\
\hline Citric acid & 191.1 & 9.18 \\
Citric acid-d4 & 195.1 & 9.02 \\
Fumaric acid & 115.1 & 11.70 \\
Glyceric acid & 105.0 & 4.94 \\
Lactic acid & 89.0 & 6.89 \\
Lactic acid-d3 & 92.1 & 6.82 \\
Maleic acid & 115.1 & 8.65 \\
Malic acid & 133.1 & 5.92 \\
Pyroglutamic acid & 128.1 & 8.80 \\
Pyruvic acid & 87.0 & 5.55 \\
Quinic acid & 191.1 & 4.94 \\
Trihydroxybutanoic acid (1) & 135.1 & 4.55 \\
Trihydroxybutanoic acid (2) & 135.1 & 4.47 \\
\hline
\end{tabular}

Two trihydroxybutanoic acids were detected in the GC-MS analysis of tobacco. Also in the LC-MS trace of extracted ion $\mathrm{m} / \mathrm{z}=135.1$ showed a split peak with a maximum at $4.55 \mathrm{~min}$ and another at $4.47 \mathrm{~min}$. The two structures of the trihydroxybutanoic acid correspond to 2,3,4-trihydroxybutanoic acid (1), and 2,3-dihydroxy-2-(hydroxymethyl)propanoic acid (2). Oxalic acid and acetic acid showed very poor sensitivity during the optimization process in LC-MS and were not quantified by the LC-MS procedure. A typical chromatogram for a standard mixture containing about $10 \mu \mathrm{g} / \mathrm{mL}$ from each analyte and about $5 \mu \mathrm{g} / \mathrm{mL}$ of deuterated standards is shown in Figure 1.

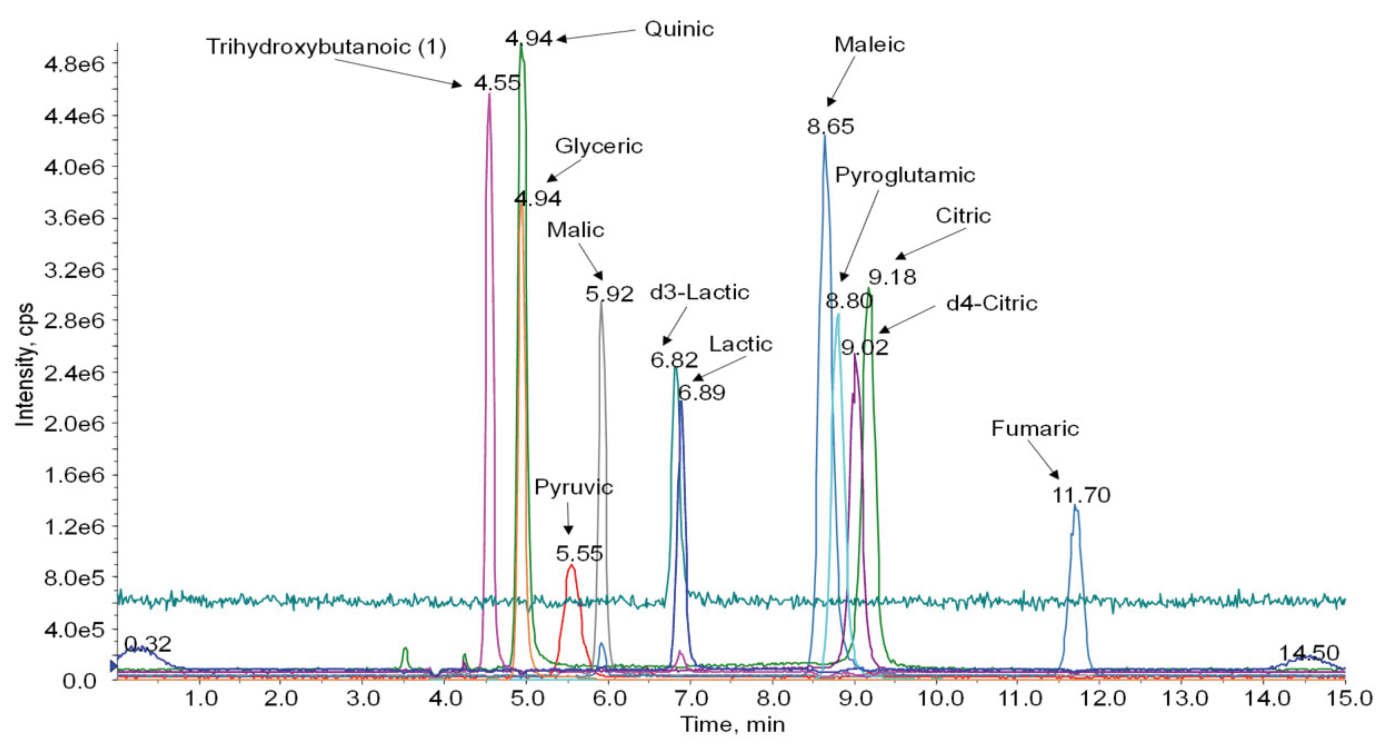

Figure 1. LC/MS chromatogram for a standard mixture containing about $5 \mu \mathrm{g} / \mathrm{mL}$ from each analyte (Std. 4 from Table 3) and about $5 \mu \mathrm{g} / \mathrm{mL}$ of deuterated standards. 
Table 3. List of standards used for calibration with $\mu \mathrm{g} / \mathrm{mL}$ compound.

\begin{tabular}{l|c|c|c|c|c|c|c|c}
\hline Compound & Std. 1 & Std. 2 & Std. 3 & Std. 4 & Std. 5 & Std. 6 & Std. 7 & Std. 8 \\
\hline Citric acid & 49.69 & 24.84 & 12.42 & 6.21 & 3.11 & 1.55 & 0.78 & 0.39 \\
Fumaric acid & 50.18 & 25.09 & 12.55 & 6.27 & 3.14 & 1.57 & 0.78 & 0.39 \\
Glyceric acid & 41.50 & 20.75 & 10.38 & 5.19 & 2.59 & 1.30 & 0.65 & 0.32 \\
Lactic acid & 49.11 & 24.56 & 12.28 & 6.14 & 3.07 & 1.53 & 0.77 & 0.38 \\
Maleic acid & 51.81 & 25.91 & 12.95 & 6.48 & 3.24 & 1.62 & 0.81 & 0.40 \\
Malic acid & 49.80 & 24.90 & 12.45 & 6.23 & 3.11 & 1.56 & 0.78 & 0.39 \\
Pyroglutamic acid & 50.86 & 25.43 & 12.72 & 6.36 & 3.18 & 1.59 & 0.79 & 0.40 \\
Pyruvic acid & 55.16 & 27.58 & 13.79 & 6.90 & 3.45 & 1.72 & 0.86 & 0.43 \\
Quinic acid & 49.56 & 24.78 & 12.39 & 6.20 & 3.10 & 1.55 & 0.77 & 0.39 \\
Trihydroxybutanoic (1) & 38.00 & 19.00 & 9.50 & 4.75 & 2.38 & 1.19 & 0.59 & 0.30 \\
\hline
\end{tabular}

Since each peak is characterized by its $\mathrm{m} / \mathrm{z}$ value, no interference was present between the analyzed compounds. Quinic and citric acids $(\mathrm{m} / \mathrm{z}=191.1)$ and fumaric and maleic acids $(\mathrm{m} / \mathrm{z}=115.1)$ were very well separated chromatographically. On the other hand, quinic and glyceric acid were not well separated chromatographically, and only the mass difference allowed the quantitation. The same lack of chromatographic separation was noticed between maleic, pyroglutamic and citric acid (each generating different ions).

\subsection{Quantitation procedure for LC-MS method}

For the quantitation by LC-MS, calibration curves were generated for all acids, except the second isomer of trihydroxybutanoic acid. The calibrations were done using seven standards. The targets for the standards were $50 \mu \mathrm{g} / \mathrm{mL}, 25 \mu \mathrm{g} / \mathrm{mL}, \quad 12.5 \mu \mathrm{g} / \mathrm{mL}, 6.25 \mu \mathrm{g} / \mathrm{mL}$, $3.125 \mu \mathrm{g} / \mathrm{mL}, 1.563 \mu \mathrm{g} / \mathrm{mL}, 0.781 \mu \mathrm{g} / \mathrm{mL}$ and $0.391 \mu \mathrm{g} / \mathrm{mL}$ of each analyte. The standards were obtained by successive dilution of an initial standard mixture. The actual concentrations of the standards are given in Table 3.

To $1 \mathrm{~mL}$ of each standard solution were added $20 \mu \mathrm{L}$ of internal standard (I.S.) containing $200.56 \mu \mathrm{g} / \mathrm{mL}$ lactic acid- $\mathrm{d}_{3}$ (as sodium salt) and $249.7 \mu \mathrm{g} / \mathrm{mL}$ citric acid- $\mathrm{d}_{4}$. Each standard solution contained the same amount of internal standard with $3.86 \mu \mathrm{g} / \mathrm{mL}$ lactic acid- $\mathrm{d}_{3}$ (as sodium salt) and $4.80 \mu \mathrm{g} / \mathrm{mL}$ citric acid- $\mathrm{d}_{4}$ (a factor of 0.98 accounts for the addition of $20 \mu \mathrm{L}$ I.S. solution to $1 \mathrm{~mL}$ standard mixtures).

Quadratic lines were found to fit better than linear ones to the calibration points.

The equations of the form $Y=a X^{2}+b X+c$ were utilized for the calibration, where $X=$ (peak area of standard) / (peak area of internal standard) and $Y$ is $\mu \mathrm{g} / \mathrm{mL}$ analyte. The values for the parameters $a, b$, and $c$, the corresponding internal standard utilized and the $R^{2}$ values for the coefficient of determination are given in Table 4 .

\subsection{Validation of the LC-MS method}

The method for acid analysis can be considered as having good specificity. Positive identification of each analyte was based on retention time, as well as each specific ion selected for detection. Additional fragmentation was not available for additional compound confirmation. In the optimization process for column selection, other columns were evaluated for the same separation. One such column was a Fortis $\mathrm{H}_{2} \mathrm{O} 100 \times 3.0 \mathrm{~mm}$ with $1.7 \mu \mathrm{m}$ particles. The separation on this column was not as good as the one on the Synergy Hydro-RP column $250 \times 4.6 \mathrm{~mm}$ with $4 \mu \mathrm{m}$ particles. Another attempt was to use two Synergy Hydro$\mathrm{RP}$ column $250 \times 4.6 \mathrm{~mm}$ with $4 \mu \mathrm{m}$ particles columns in series. The chromatographic separation was better on two columns than on a single column, but the use of the two columns was found unnecessary.

Table 4. Coefficients $a, b$, and $c$ for the equations for the quantitation of the analytes, the utilized internal standard, and coefficient $\mathbf{R}^{2}$ of determination for the analytes.

\begin{tabular}{|c|c|c|c|c|c|}
\hline Compound & I.S. & a & $b$ & c & $\mathrm{R}^{2}$ \\
\hline Citric acid & Citric acid- $\mathrm{d}_{4}$ & 3.55189 & 2.68302 & 0.29289 & 0.9907 \\
\hline Fumaric acid & Citric acid- $\mathrm{d}_{4}$ & 8.12466 & 11.36317 & 0.07050 & 0.9991 \\
\hline Glyceric acid & 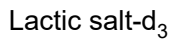 & 1.95251 & 2.42061 & 0.07033 & 0.9978 \\
\hline Lactic acid & 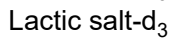 & 1.65498 & 6.40531 & -0.04869 & 0.9979 \\
\hline Maleic acid & Citric acid- $\mathrm{d}_{4}$ & 1.59210 & 1.16339 & 0.05186 & 0.9993 \\
\hline Malic acid & 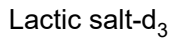 & 1.69472 & 4.25522 & 0.28346 & 0.9991 \\
\hline Pyroglutamic acid & Citric acid- $\mathrm{d}_{4}$ & 5.03816 & 2.06951 & 0.23499 & 0.9909 \\
\hline Pyruvic acid & 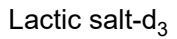 & 0.03721 & 9.13219 & -0.01613 & 0.9997 \\
\hline Quinic acid & Lactic salt- $_{3}$ & 1.13568 & -0.49185 & 0.43686 & 0.9938 \\
\hline Trihydroxybutanoic acid & Lactic salt- $d_{3}$ & 2.07387 & 0.51932 & 0.19828 & 0.9919 \\
\hline
\end{tabular}

The quantitation of trihydroxybutanoic acid (2) was performed using the parameters for trihydroxybutanoic acid (1). 
The precision of the method was verified only using six repeated injections for the standard with $\sim 1.25 \mu \mathrm{g} / \mathrm{mL}$. The RSD $\%$ obtained for each acid were: citric $5.9 \%$, fumaric $8.6 \%$, lactic $4.2 \%$, maleic $6.3 \%$, malic $4.8 \%$, pyruvic $4.5 \%$, and quinic $6.0 \%$. Precision was further evaluated on repeated samples injections. The range of concentrations of organic acids in tobacco and oral tobacco products can vary significantly (up to three orders of magnitude). For this reason, besides $1-\mu \mathrm{L}$ injections, injections of $0.5 \mu \mathrm{L}$ and $5 \mu \mathrm{L}$ were also evaluated. All three levels of injection provided basically the same results. However, the precision in the measurement for the acids present at a larger level in tobacco (malic, citric, quinic, trihydroxybutanoic) injections of $0.5 \mu \mathrm{L}$ and $1 \mu \mathrm{L}$ gave better precision, while for the lower levels acids (pyruvic, maleic, and fumaric), an injection of $5 \mu \mathrm{L}$ generated better precision (for $5-\mu \mathrm{L}$ injections the internal standard was diluted five times to generate peak areas similar to those obtained using $1-\mu \mathrm{L}$ injection).

Method accuracy has been evaluated with available data for citric acid, measured using a LC-UV procedure. In this procedure the separation was performed on the same type of column as for LC-MS, but using as mobile phase a solution $20 \mathrm{mM} \mathrm{KH} \mathrm{PO}_{4}$ brought at $\mathrm{pH} 2.6$ with $\mathrm{H}_{3} \mathrm{PO}_{4}$. The injection was $20 \mu \mathrm{L}$ and the measurement was based on UV absorption at $215 \mathrm{~nm}$. The comparison of the results on a set of 24 samples is shown in Figure 2.

The validation was further performed regarding limits of detection and quantitation (LOD and LOQ), range of quantitation, precision, extraction efficiency, as well as solutions stability (see e.g., (20)). The limit of detection (LOD) and limit of quantitation (LOQ) were established only using standards (no residual matrix components were used in the determinations to establish a practical LOD or LOQ). For establishing LOD and LOQ, a serial dilution was continued using the most diluted working standard (that contained about $0.625 \mu \mathrm{g} / \mathrm{mL}$ of acids). This serial dilution $(1 / 2,1 / 4,1 / 8$, etc.) was used to determine when signal to noise $(\mathrm{S} / \mathrm{N})$ values for an individual acid peak is $\approx 10$ for LOQ evaluation. The values for LOQ are listed in Table 5. The values for LOD corresponding to a $\mathrm{S} / \mathrm{N} \approx 3$ can be estimated as 3.3 times lower than LOQ, but these values were not directly measured.

As shown in Table 5, the LOQ values for different analytes vary significantly. Some acids such as quinic, malic, and maleic have low LOQ values, while other acids have higher LOQ. However, all limits of detection refer to the solutions of standards and not of samples. The plant material extract was diluted significantly (equivalent to the extraction of $50 \mathrm{mg}$ sample in $60 \mathrm{~mL}$ solution). This dilution could be reduced so very low concentrations of the analyzed acids could be measured, if necessary.

Regarding the range of quantitation, all calibrations were quadratic, and the acid levels in the measured samples were in most cases within the calibration range. For cases when the result indicated values larger than the highest calibration point, a dilution was made to bring the level in the analyzed solution within the range of calibration.

The extraction efficiency of the organic acids from the plant material was evaluated for two different samples: a moist snuff and a tobacco. The samples were extracted for three different lengths of time: $15 \mathrm{~min}, 30 \mathrm{~min}$, and $60 \mathrm{~min}$. Differences less than $5 \%$ in the results for all analytes were obtained for all three extraction times. However, all samples were extracted for $30 \mathrm{~min}$ (as indicated in the experimental section). The use of different extracting solutions was also evaluated. Water with $0.1 \%$ formic acid was found adequate for extracting all acids from plant material, except for oxalic acid. Oxalic acid can be present in the plant material as calcium salt, and for its complete extraction, a solution $0.15 \% \mathrm{H}_{2} \mathrm{SO}_{4}$ was found necessary. However, since oxalic acid was not generating a good response in the MS detection, this compound was not further included in the analytes measured by the proposed method.

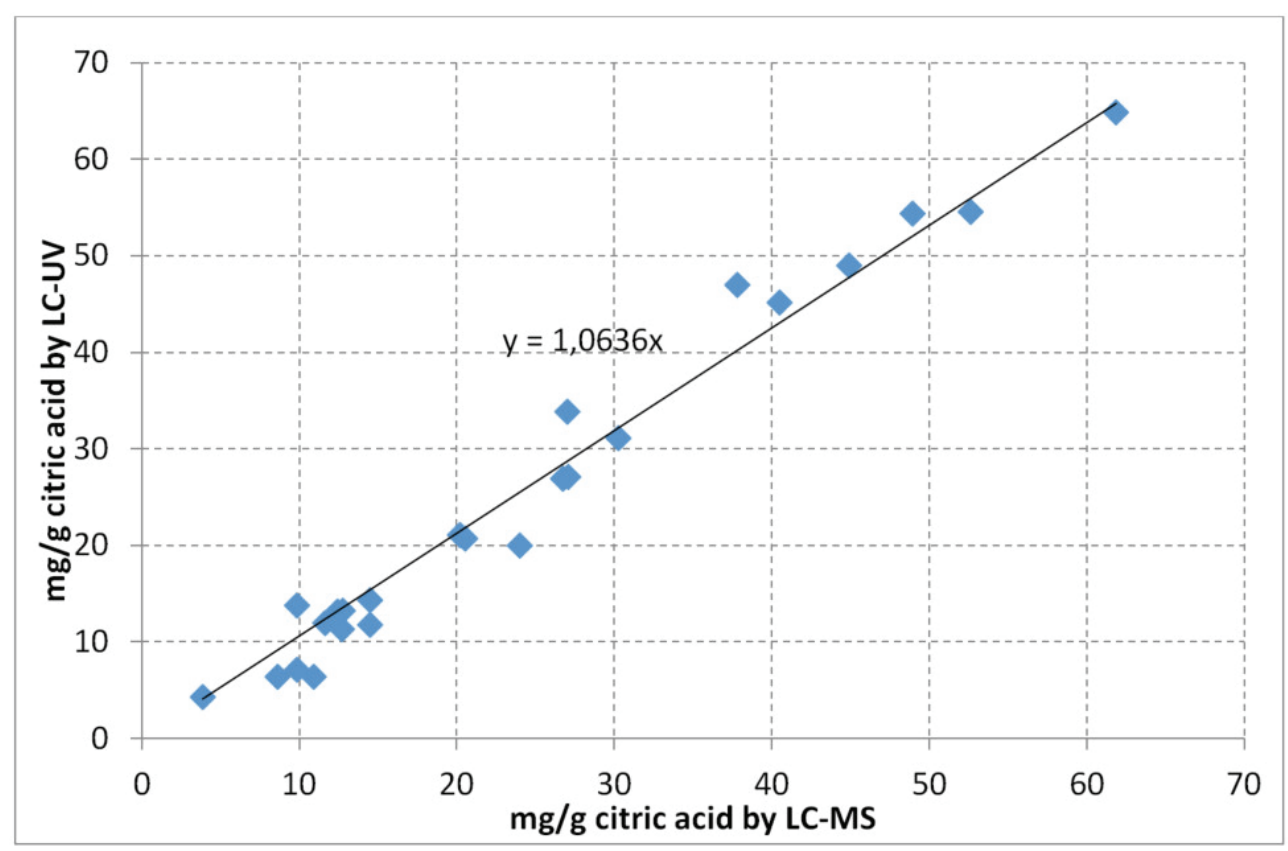

Figure 2. Comparison of the data for citric acid obtained using the LC-MS method and a LC-UV method. 
Table 5. The values for LOD and LOQ in the analyzed solutions and sample for various analytes.

\begin{tabular}{l|cc|c}
\hline Compound & $\begin{array}{c}\text { LOD } \\
(\mu \mathrm{g} / \mathrm{mL} \text { solution })\end{array}$ & $\begin{array}{c}\mathrm{LOQ} \\
(\mu \mathrm{g} / \mathrm{mL} \text { solution })\end{array}$ & $\begin{array}{c}\mathrm{LOQ} \\
(\mu \mathrm{g} / \mathrm{g} \text { sample })\end{array}$ \\
\hline Citric acid & 0.037 & 0.111 & 166.4 \\
Fumaric acid & 0.009 & 0.028 & 41.9 \\
Glyceric acid & 0.003 & 0.011 & 15.9 \\
Lactic acid & 0.020 & 0.062 & 92.5 \\
Maleic acid & 0.004 & 0.012 & 17.6 \\
Malic acid & 0.007 & 0.021 & 32.0 \\
Pyroglutamic & 0.005 & 0.014 & 21.0 \\
$\quad$ acid & 0.009 & 0.029 & 42.9 \\
Pyruvic acid & 0.001 & 0.004 & 5.5 \\
Quinic acid & 0.008 & 0.023 & 34.1 \\
Trihydroxy- & & & \\
butanoic acid (1) & & &
\end{tabular}

Addition of a specific level of analyte solution to the sample followed by an attempt to recover the addition was also performed in this study. To the extract of a 3R4F Kentucky reference tobacco a standard mixture of acids has been added to account for about $9 \mu \mathrm{g} / \mathrm{mL}$ acid. The results are indicated in Table 6.

As shown in Table 6, all the recoveries are good, within $10 \%$ RSD from the added amount, except for pyruvic acid which showed a slightly lower recovery.

Other aspects related to the validation of this method were verified. This included the stability of the extracted samples when stored at about $5{ }^{\circ} \mathrm{C}$ in the autosampler or in a refrigerator. The samples were stable for at least two weeks without any change in the analytes content (within 5\% RSD).

\section{RESULTS AND DISCUSSION}

\subsection{Sample description}

The analysis of organic acids in plant materials was performed on a number of samples listed in Table 7. The table also indicates the moisture of each sample as moisture/oven volatiles in $\%$.

\subsection{GC-MS results}

GC-MS analysis has been performed on several samples listed in Table 7. A total ion chromatogram of the silylated sample (Spl.) 25 (from Table 7) is shown in Figure 3.

The identification of the main compounds listed in the order of their retention times, corresponding to the peaks in Figure 3, is given in Table 8 .

Some acids such as acetic and oxalic, although potentially present in the tobacco cannot be analyzed by the GC-MS technique used in this study.

As indicated in Table 8, tobacco samples contain a considerable number of organic acids. The other analyzed sample using the same procedure, showed basically the same list of compounds, although at different levels compared to Spl. 25. Only a limited number of acids identified in tobacco were further quantitated. These included citric, fumaric, glyceric, lactic, maleic, malic, pyroglutamic, pyruvic, quinic, and trihydroxybutanoic acids. These represented the acids at relatively higher content in most tobacco samples. Several other acids, although qualitatively detected in tobacco, were not quantitated. These include the following acids: glycolic, succinic, aspartic, glutamic, tetrahydroxypentanoic, 2-keto-L-gluconic, gluconic, galactaric, hexadecanoic, caffeic, linoleic, linolenic, glucuronic, and chlorogenic(s). Some of these acids were not expected to be properly analyzed by the LC-MS technique described in this study. These include hexadecanoic, caffeic, linoleic, linolenic, and chlorogenic(s) acids. Other acids, such as the sugar-related ones (tetrahydroxypentanoic, 2-keto-L-gluconic, gluconic, galactaric, and glucuronic), according to the TIC trace, are at very low levels and were not included in the list for quantitation. Also, some amino acids (aspartic, glutamic) were not quantitated in this study. Glycolic and succinic acids also were not quantitated being at low levels. In addition, glycolic acid having a small molecule was not expected to generate a good response in the LC-MS analysis.

Table 6. Recovery results upon the addition of about $9 \mu \mathrm{g} / \mathrm{mL}$ acids to a 3R4F Kentucky reference tobacco extract.

\begin{tabular}{|c|c|c|c|c|c|c|}
\hline Compound & $\begin{array}{l}\text { Average 3R4F } \\
(\mu \mathrm{g} / \mathrm{mL})\end{array}$ & $\begin{array}{l}\text { RSD } \\
(\%)\end{array}$ & $\begin{array}{l}\text { Added } \\
(\mu \mathrm{g} / \mathrm{mL})\end{array}$ & $\begin{array}{l}\text { Measured } \\
(\mu \mathrm{g} / \mathrm{mL})\end{array}$ & $\begin{array}{l}\text { RSD } \\
(\%)\end{array}$ & $\begin{array}{c}\text { Recovery } \\
(\%)\end{array}$ \\
\hline Citric acid & 11.30 & 4.07 & 9.69 & 21.31 & 8.76 & 103.30 \\
\hline Fumaric acid & 0.12 & 2.38 & 8.73 & 8.51 & 3.48 & 96.10 \\
\hline Glyceric acid & 0.68 & 2.35 & 10.22 & 11.43 & 14.93 & 105.19 \\
\hline Lactic acid & 0.77 & 2.24 & 9.20 & 10.34 & 6.09 & 104.02 \\
\hline Maleic acid & 0.06 & 0.46 & 7.75 & 7.05 & 12.14 & 90.50 \\
\hline Malic acid & 39.96 & 5.95 & 9.22 & 48.40 & 1.92 & 102.38 \\
\hline Pyroglutamic acid & 1.06 & 2.44 & 10.36 & 11.67 & 3.95 & 102.41 \\
\hline Pyruvic acid & 0.20 & 8.03 & 8.92 & 8.10 & 9.68 & 88.56 \\
\hline Quinic acid & 4.18 & 4.65 & 9.17 & 14.03 & 4.73 & 107.41 \\
\hline Trihydroxybutanoic acid & 2.47 & 3.76 & 9.94 & 12.65 & 4.73 & 102.41 \\
\hline
\end{tabular}


Table 7. List of samples analyzed in this study and their moisture/oven volatiles.

\begin{tabular}{|c|c|c|c|}
\hline No. & Tobacco Sample & Description & Moisture (\%) \\
\hline 1 & Snus 1 & Natural & 28.93 \\
\hline 2 & Snus 2 & Wintergreen & 26.96 \\
\hline 3 & Snus 3 & Mint & 51.16 \\
\hline 4 & Snus 4 & Wintergreen & 51.58 \\
\hline 5 & Moist snuff 1 & Natural & 49.73 \\
\hline 6 & Moist snuff 2 & Natural & 49.38 \\
\hline 7 & Moist snuff 3 & Natural & 51.06 \\
\hline 8 & Moist snuff 4 & Natural & 51.06 \\
\hline 9 & Moist snuff 5 & Wintergreen & 50.20 \\
\hline 10 & Moist snuff 6 & Wintergreen & 54.47 \\
\hline 11 & $\mathrm{FC} \mathrm{L} \mathrm{(1)}$ & Eastern NC belt, lower stalk (lug) flue-cured & 8.21 \\
\hline 12 & $F C \cup(1)$ & Eastern NC belt, upper stalk (leaf \& some tips) flue-cured & 9.63 \\
\hline 13 & FC L (2) & South Carolina belt, lower stalk (lug) flue-cured & 10.18 \\
\hline 14 & $\mathrm{FC} \cup(2)$ & South Carolina belt, upper stalk (leaf \& some tips) flue-cured & 12.25 \\
\hline 15 & FC off $L$ & Brazil, lower stalk (lugs \& primings) flue-cured & 10.45 \\
\hline 16 & FC off U & Brazil, upper stalk (leaf \& tips) flue-cured & 9.85 \\
\hline 17 & $\mathrm{Bu} \mathrm{L}(1)$ & Kentucky \& Tennessee, lower stalk (flyings \& cutters) burley & 7.89 \\
\hline 18 & $\mathrm{Bu} \cup(1)$ & Kentucky \& Tennessee, upper stalk (leaf) burley & 7.63 \\
\hline 19 & $\mathrm{Bu} L(2)$ & North Carolina \& Virginia, lower stalk (flyings \& cutters) burley & 9.31 \\
\hline 20 & $\mathrm{Bu} \cup(2)$ & North Carolina \& Virginia, upper stalk (leaf) burley & 8.21 \\
\hline 21 & Bu off $L$ & Malawi, lower stalk (flyings \& cutters) burley & 10.8 \\
\hline 22 & Bu off $U$ & Malawi, upper stalk (leaf) burley & 10.63 \\
\hline 23 & O SA U & Turkey, good quality middle to upper stalk, Samsun oriental & 7.74 \\
\hline 24 & $\mathrm{OlzU}$ & Turkey, good quality middle to upper stalk, Izmir oriental & 10.2 \\
\hline 25 & Commercial cigarette & Tobacco blend & 9.21 \\
\hline 26 & 3R4F cigarette & Tobacco blend & 8.46 \\
\hline
\end{tabular}

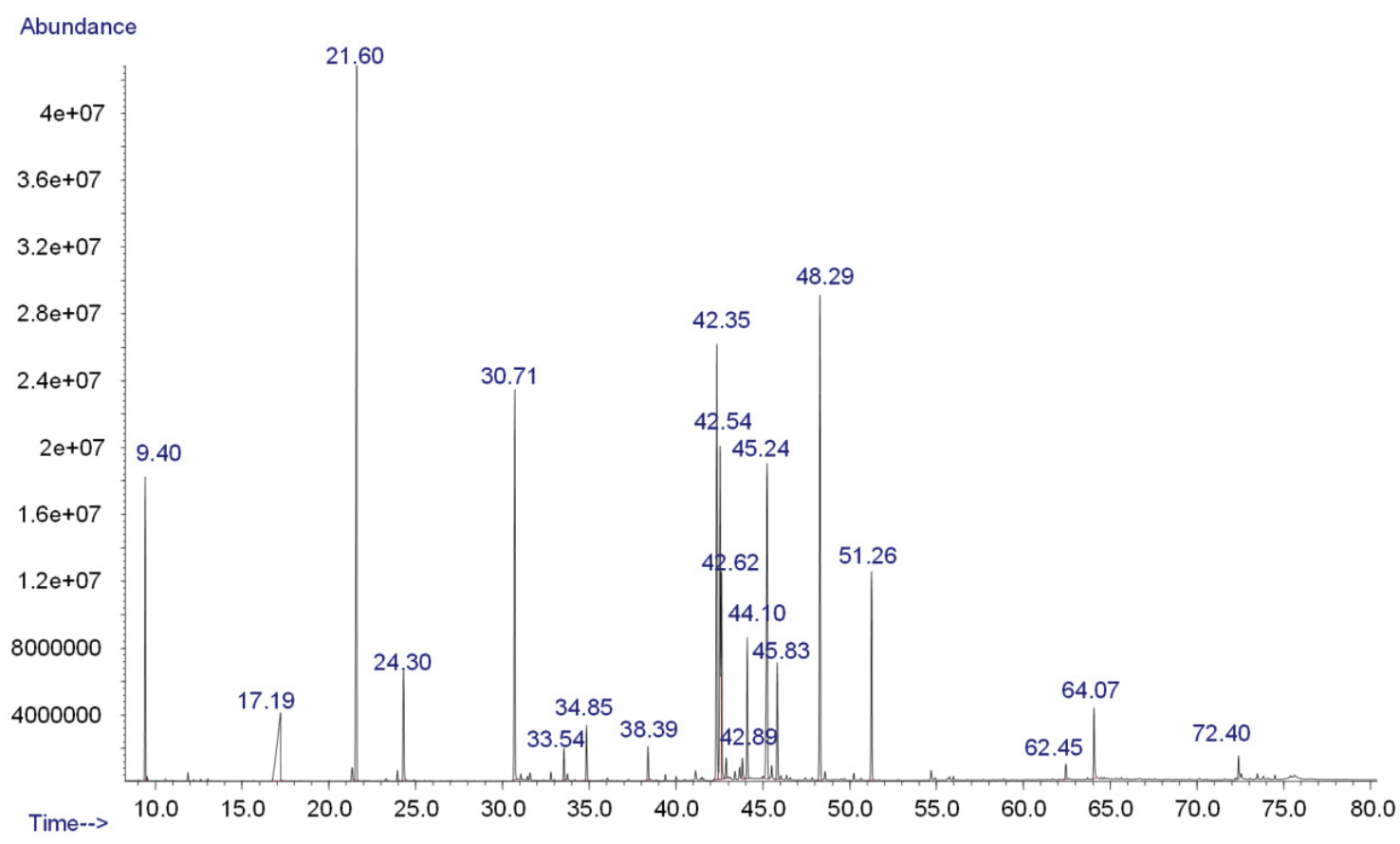

Figure 3. GC/MS total ion chromatogram of a silylated tobacco sample (Spl. 25), with peak identification listed in Table 8. The peak at $34.85 \mathrm{~min}$ is the internal standard tert-butylhydroquinone. 
Table 8. List of main compounds identified in the chromatogram of silylated tobacco sample.

\begin{tabular}{|c|c|c|c|c|c|}
\hline Peak \# & Compound & $\begin{array}{c}\text { Retention time } \\
(\min )\end{array}$ & Peak \# & Compound & $\begin{array}{l}\text { Retention time } \\
\text { (min) }\end{array}$ \\
\hline 1 & Propylene glycol & 9.40 & 31 & Citric acid* & 42.89 \\
\hline 2 & Lactic acid* & 11.87 & 32 & Neophytadiene & 43.40 \\
\hline 3 & Glycolic acid & 12.61 & 33 & Quinic acid* & 44.10 \\
\hline 4 & Alanine & 13.00 & 34 & Glucose (1) & 45.24 \\
\hline 5 & Pyruvic acid* & 15.65 & 35 & Inositol type? & 45.83 \\
\hline 6 & Phosphate & 21.32 & 36 & Glucosamine & 46.04 \\
\hline 7 & Glycerin & 21.60 & 37 & Mannitol & 46.37 \\
\hline 8 & Succinic acid & 23.28 & 38 & Sorbitol & 46.58 \\
\hline 9 & Glyceric acid* & 23.94 & 39 & Glucose (2) & 48.29 \\
\hline 10 & Nicotine & 24.30 & 40 & Gluconic acid & 48.59 \\
\hline 11 & 2-Butenedioic acid $(\mathrm{E} \text {, and } \mathrm{Z})^{*}$ & 24.90 & 41 & Galactaric acid & 48.83 \\
\hline 12 & Malic acid* & 30.71 & 42 & Hexadecanoic acid & 50.24 \\
\hline 13 & Pyroglutamic acid* & 31.59 & 43 & Myoinositol & 51.26 \\
\hline 14 & Aspartic acid & 31.88 & 44 & Caffeic acid & 52.81 \\
\hline 15 & Trihydroxybutanoic acid $(1)^{*}$ & 32.80 & 45 & Linoleic acid & 54.77 \\
\hline 16 & Trihydroxybutanoic acid $(2)^{*}$ & 33.54 & 46 & Linolenic acid & 54.91 \\
\hline 17 & Arabinose & 35.46 & 47 & Galactopyranose & 55.75 \\
\hline 18 & Rhamnose & 36.00 & 48 & Glucuronic acid & 58.88 \\
\hline 19 & Glutamic acid & 35.77 & 49 & Disaccharide & 62.45 \\
\hline 20 & Ribose & 37.26 & 50 & Phytosterol (1) & 63.70 \\
\hline 21 & Asparagine & 37.52 & 51 & Sucrose & 64.07 \\
\hline 22 & Levoglucosan & 38.55 & 52 & 2,5-Deoxyfructosazine & 64.50 \\
\hline 23 & Xylitol & 39.39 & 53 & 2,6-Deoxyfructosazine & 64.66 \\
\hline 24 & Xylose & 39.39 & 54 & Maltose & 65.66 \\
\hline 25 & Tetrahydroxypentanoic acid & 40.45 & 55 & Maltitol & 67.23 \\
\hline 26 & 2-Keto-L-gluconic acid & 40.87 & 56 & Chlorogenic acid (1) & 72.40 \\
\hline 27 & Mannose & 43.67 & 57 & Tocoferol & 72.56 \\
\hline 28 & Fructose (1) & 42.35 & 58 & Chlorogenic acid (2) & 73.83 \\
\hline 29 & Fructose (2) & 42.54 & 59 & Stigmasterol & 74.51 \\
\hline 30 & Fructose (3) & 42.62 & 60 & Trisaccharide & 73.06 \\
\hline
\end{tabular}

* Note: Acids further quantitated by the HPLC procedure.

\subsection{LC-MS results}

The levels of citric, fumaric, glyceric, lactic, maleic, malic, pyroglutamic, pyruvic, quinic, and trihydroxybutanoic (two isomers) were further quantitated in several samples of snus, wet snuff, and tobacco samples. A chromatogram obtained for Spl. 11 (FC L (1) is shown in Figure 4 as an example. All samples were analyzed in triplicate. The results are further presented in Table 9.

The results from Table 9 indicate that different organic acids from tobacco and oral tobacco products are at significantly different levels. Citric, malic, and quinic acids can be at levels as high as $1 \%$ to $4 \%$, lactic and trihydroxybutanoic acids at levels around $1-2 \mathrm{mg} / \mathrm{g}$. Fumaric, maleic, and pyruvic acids were typically at $\mu \mathrm{g} / \mathrm{g}$ levels. Also, the levels of any analyzed acid varied considerably from sample to sample. The precision of the analyses can be considered very good for the acids present at higher levels (citric, malic, and quinic), and good for the acids at lower levels that show most RSD\% values below 10\%. Only the precision for pyruvic acid was not very good.

\section{CONCLUSIONS}

Present study describes a LC-MS procedure for the quantitation of several organic acids common in tobacco and oral tobacco products. The analysis started with a GCMS technique for qualitative identification of the acids that was followed by quantitation using a novel LC-MS technique. The acids measured in the samples included citric, fumaric, glyceric, lactic, maleic, malic, pyroglutamic, pyruvic, quinic, and trihydroxybutanoic acids. Acetic and oxalic acids were not quantitated by this procedure since the attempts for calibration with standards indicated poor sensitivity. The quantitative LC-MS procedure was validated following steps commonly required in the literature for this purpose. The results showed large differences in the acids content from tobacco to tobacco, or between snus and wet snuff samples. 


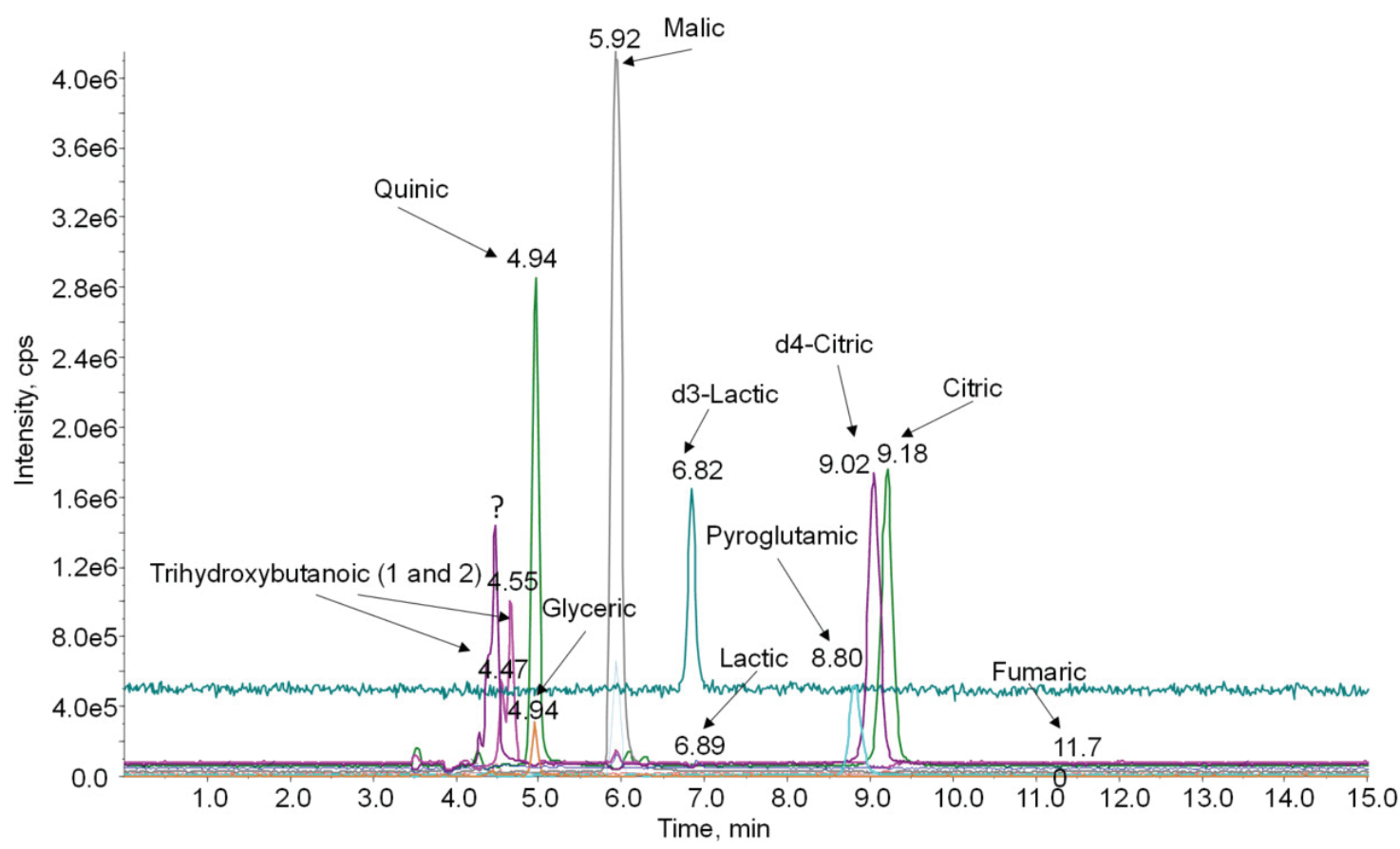

Figure 4. LC/MS chromatogram of sample Spl. 11 (FC L (1)), with deuterated standards.

Table 9. Results of levels of organic acids in $\mathrm{mg} / \mathrm{g}$ in the analyzed samples (expressed on a dry basis.)

\begin{tabular}{|c|c|c|c|c|c|c|c|c|c|}
\hline No. & Sample & $\begin{array}{l}\text { Citric } \\
(\mathrm{mg} / \mathrm{g})\end{array}$ & $\begin{array}{l}\text { RSD } \\
(\%)\end{array}$ & $\begin{array}{c}\text { Fumaric } \\
(\mathrm{mg} / \mathrm{g})\end{array}$ & $\begin{array}{l}\text { RSD } \\
(\%)\end{array}$ & $\begin{array}{c}\text { Glyceric } \\
(\mathrm{mg} / \mathrm{g})\end{array}$ & $\begin{array}{c}\text { RSD } \\
(\%)\end{array}$ & $\begin{array}{l}\text { Lactic } \\
(\mathrm{mg} / \mathrm{g})\end{array}$ & $\begin{array}{c}\text { RSD } \\
(\%)\end{array}$ \\
\hline 1 & Snus 1 & 31.06 & 1.92 & 0.17 & 4.31 & 2.60 & 7.53 & 0.60 & 6.44 \\
\hline 2 & Snus 2 & 27.07 & 0.90 & 0.18 & 4.62 & 2.63 & 3.02 & 0.56 & 4.19 \\
\hline 3 & Snus 3 & 11.75 & 1.03 & 0.10 & 6.32 & 2.03 & 1.87 & 0.56 & 4.39 \\
\hline 4 & Snus 4 & 18.58 & 1.37 & 0.11 & 8.66 & 2.10 & 2.74 & 0.58 & 5.97 \\
\hline 5 & Moist snuff 1 & 13.09 & 1.92 & 0.22 & 5.17 & 0.33 & 2.93 & 0.52 & 3.49 \\
\hline 6 & Moist snuff 2 & 13.71 & 1.84 & 0.24 & 4.84 & 0.34 & 4.29 & 0.51 & 1.74 \\
\hline 7 & Moist snuff 3 & 1.03 & 0.79 & 0.08 & 14.01 & 0.37 & 1.17 & 0.19 & 4.39 \\
\hline 8 & Moist snuff 4 & 26.87 & 1.49 & 0.24 & 1.76 & 0.29 & 4.65 & 0.31 & 5.57 \\
\hline 9 & Moist snuff 5 & 33.81 & 1.32 & 0.55 & 0.18 & 1.15 & 0.78 & 0.73 & 1.70 \\
\hline 10 & Moist snuff 6 & 4.29 & 1.34 & 0.10 & 11.40 & 0.37 & 3.51 & 0.60 & 3.30 \\
\hline 11 & FC L (1) & 14.32 & 1.80 & 0.15 & 5.67 & 1.07 & 6.32 & 0.29 & 5.66 \\
\hline 12 & $\mathrm{FC} \cup(1)$ & 11.31 & 1.60 & 0.11 & 9.05 & 1.07 & 3.73 & 0.28 & 1.36 \\
\hline 13 & FC L (2) & 13.23 & 1.92 & 0.13 & 5.91 & 1.10 & 2.42 & 0.37 & 2.27 \\
\hline 14 & $\mathrm{FC} \cup(2)$ & 6.33 & 2.28 & 0.13 & 2.81 & 0.87 & 1.50 & 0.29 & 4.34 \\
\hline 15 & FC off $L$ & 11.88 & 1.63 & 0.13 & 14.01 & 1.36 & 4.06 & 0.38 & 1.80 \\
\hline 16 & FC off U & 6.39 & 1.96 & 0.06 & 17.92 & 1.37 & 2.73 & 0.49 & 4.99 \\
\hline 17 & $\mathrm{Bu} \mathrm{L} \mathrm{(1)}$ & 64.82 & 1.94 & 0.26 & 3.70 & 0.82 & 4.43 & 0.21 & 3.65 \\
\hline 18 & $\mathrm{Bu} \cup(1)$ & 48.94 & 2.56 & 0.33 & 4.16 & 1.02 & 3.94 & 0.22 & 3.73 \\
\hline 19 & $\mathrm{Bu} L(2)$ & 45.09 & 0.23 & 0.34 & 2.35 & 0.96 & 2.44 & 0.25 & 3.54 \\
\hline 20 & $\mathrm{Bu} \cup(2)$ & 46.91 & 2.60 & 0.57 & 4.02 & 0.97 & 0.75 & 0.25 & 3.45 \\
\hline 21 & Bu off $L$ & 54.51 & 1.44 & 0.80 & 5.12 & 1.68 & 1.51 & 0.23 & 6.20 \\
\hline 22 & Bu off $U$ & 54.31 & 1.79 & 1.14 & 0.93 & 1.78 & 1.90 & 0.31 & 4.57 \\
\hline 23 & O SA U & 19.93 & 0.67 & 0.14 & 5.61 & 1.39 & 2.38 & 0.26 & 4.16 \\
\hline 24 & $\mathrm{OlzU}$ & 7.09 & 1.30 & 0.08 & 11.46 & 1.14 & 6.68 & 0.33 & 3.73 \\
\hline 25 & Commercial cigarette & 21.08 & 1.69 & 0.16 & 1.20 & 1.22 & 3.01 & 0.62 & 3.99 \\
\hline 26 & 3R4F cigarette & 20.70 & 1.77 & 0.19 & 3.20 & 1.22 & 3.73 & 0.81 & 4.93 \\
\hline
\end{tabular}


Table 9. (cont.) Results of levels of organic acids in $\mathrm{mg} / \mathrm{g}$ in the analyzed samples (expressed on a dry basis.)

\begin{tabular}{|c|c|c|c|c|c|c|c|}
\hline No. & Sample & $\begin{array}{c}\text { Maleic }{ }^{*} \\
(\mathrm{mg} / \mathrm{g})\end{array}$ & $\begin{array}{l}\text { RSD } \\
(\%)\end{array}$ & $\begin{array}{l}\text { Malic } \\
(\mathrm{mg} / \mathrm{g})\end{array}$ & $\begin{array}{l}\text { RSD } \\
(\%)\end{array}$ & $\begin{array}{l}\text { Pyroglutamic } \\
(\mathrm{mg} / \mathrm{g})\end{array}$ & $\begin{array}{c}\text { RSD } \\
(\%)\end{array}$ \\
\hline 1 & Snus 1 & 0.05 & 7.14 & 39.83 & 10.41 & 2.79 & 2.22 \\
\hline 2 & Snus 2 & 0.05 & 10.63 & 39.58 & 8.69 & 2.30 & 1.00 \\
\hline 3 & Snus 3 & 0.06 & 3.00 & 32.62 & 7.32 & 2.87 & 0.45 \\
\hline 4 & Snus 4 & 0.06 & 3.39 & 38.61 & 6.64 & 3.38 & 2.30 \\
\hline 5 & Moist snuff 1 & 0.06 & 4.72 & 2.83 & 2.67 & 3.62 & 1.45 \\
\hline 6 & Moist snuff 2 & 0.06 & 3.73 & 0.89 & 2.79 & 3.93 & 3.35 \\
\hline 7 & Moist snuff 3 & 0.06 & 2.32 & 0.55 & 1.18 & 4.33 & 1.59 \\
\hline 8 & Moist snuff 4 & 0.06 & 3.55 & 1.21 & 1.87 & 2.95 & 1.32 \\
\hline 9 & Moist snuff 5 & 0.06 & 3.32 & 11.21 & 3.09 & 1.59 & 2.87 \\
\hline 10 & Moist snuff 6 & 0.06 & 2.16 & 2.09 & 4.95 & 4.09 & 1.73 \\
\hline 11 & $\mathrm{FC} \mathrm{L} \mathrm{(1)}$ & 0.06 & 0.74 & 52.25 & 10.75 & 1.75 & 2.29 \\
\hline 12 & $\mathrm{FC} \cup(1)$ & 0.06 & 1.58 & 36.85 & 6.63 & 1.68 & 1.81 \\
\hline 13 & FC L (2) & 0.06 & 1.15 & 58.19 & 8.51 & 1.67 & 1.60 \\
\hline 14 & $\mathrm{FC} \cup(2)$ & 0.06 & 0.94 & 31.03 & 2.76 & 1.34 & 0.69 \\
\hline 15 & $F C$ off $L$ & 0.06 & 1.82 & 60.06 & 6.15 & 1.70 & 1.37 \\
\hline 16 & FC off U & 0.06 & 2.11 & 47.87 & 7.95 & 1.55 & 0.94 \\
\hline 17 & $\mathrm{Bu} L(1)$ & 0.07 & 5.95 & 50.46 & 10.00 & 0.86 & 1.50 \\
\hline 18 & $\mathrm{Bu} \cup(1)$ & 0.06 & 4.28 & 45.91 & 6.18 & 1.57 & 2.30 \\
\hline 19 & $\mathrm{Bu} L(2)$ & 0.06 & 2.56 & 29.55 & 4.10 & 0.72 & 0.44 \\
\hline 20 & $\mathrm{Bu} \cup(2)$ & 0.06 & 1.08 & 27.01 & 4.60 & 0.77 & 0.91 \\
\hline 21 & Bu off $L$ & 0.06 & 2.13 & 38.42 & 7.40 & 1.59 & 1.37 \\
\hline 22 & Bu off $U$ & 0.06 & 6.51 & 44.13 & 1.96 & 2.20 & 1.38 \\
\hline 23 & O SA U & 0.06 & 1.23 & 44.94 & 2.81 & 5.74 & 3.15 \\
\hline 24 & $\mathrm{O} I z \mathrm{U}$ & 0.06 & 2.55 & 33.37 & 11.55 & 0.81 & 1.51 \\
\hline 25 & Commercial cigarette & 0.06 & 2.73 & 41.02 & 3.01 & 1.63 & 1.25 \\
\hline 26 & 3R4F cigarette & 0.06 & 1.74 & 40.22 & 10.31 & 1.30 & 2.20 \\
\hline
\end{tabular}

* Note: All samples had the maleic acid at levels below the lowest standard.

Table 9. (cont.) Results of levels of organic acids in $\mathrm{mg} / \mathrm{g}$ in the analyzed samples (expressed on a dry basis).

\begin{tabular}{|c|c|c|c|c|c|c|c|}
\hline No. & Sample & $\begin{array}{c}\text { Pyruvic } \\
\text { (mg/g) }\end{array}$ & $\begin{array}{l}\text { RSD } \\
(\%)\end{array}$ & $\begin{array}{l}\text { Quinic } \\
(\mathrm{mg} / \mathrm{g})\end{array}$ & $\begin{array}{l}\text { RSD } \\
(\%)\end{array}$ & $\begin{array}{l}\text { Trihydr. } \\
(\mathrm{mg} / \mathrm{g})\end{array}$ & $\begin{array}{l}\text { RSD } \\
(\%)\end{array}$ \\
\hline 1 & Snus 1 & $0.08^{*}$ & 16.16 & 11.15 & 11.41 & 5.72 & 6.71 \\
\hline 2 & Snus 2 & $0.16^{*}$ & 25.98 & 11.49 & 5.23 & 5.36 & 3.91 \\
\hline 3 & Snus 3 & $0.17^{*}$ & 26.72 & 9.30 & 5.75 & 4.63 & 3.19 \\
\hline 4 & Snus 4 & N.D. ** & N.D. & 10.05 & 10.48 & 4.96 & 2.22 \\
\hline 5 & Moist snuff 1 & $0.13^{*}$ & 28.64 & 6.20 & 7.26 & 0.31 & 2.74 \\
\hline 6 & Moist snuff 2 & N.D. & N.D. & 5.89 & 1.16 & 0.55 & 2.48 \\
\hline 7 & Moist snuff 3 & N.D. & N.D. & 1.24 & 1.58 & 0.32 & 5.35 \\
\hline 8 & Moist snuff 4 & N.D. & N.D. & 3.80 & 5.40 & 0.85 & 11.69 \\
\hline 9 & Moist snuff 5 & N.D. & N.D. & 3.49 & 5.52 & 1.39 & 5.07 \\
\hline 10 & Moist snuff 6 & 0.69 & 36.29 & 2.53 & 6.52 & 0.29 & 4.47 \\
\hline 11 & $\mathrm{FC} \mathrm{L} \mathrm{(1)}$ & N.D. & N.D. & 5.66 & 11.51 & 3.53 & 9.22 \\
\hline 12 & $F C \cup(1)$ & N.D. & N.D. & 6.79 & 9.94 & 3.67 & 3.04 \\
\hline 13 & FC L (2) & N.D. & N.D. & 6.62 & 10.08 & 4.08 & 5.24 \\
\hline 14 & $\mathrm{FC} \cup(2)$ & N.D. & N.D. & 6.40 & 4.55 & 4.02 & 2.68 \\
\hline 15 & FC off $L$ & $0.11^{*}$ & 22.97 & 10.88 & 11.10 & 5.37 & 5.30 \\
\hline 16 & FC off $U$ & N.D. & N.D. & 12.76 & 7.65 & 5.46 & 6.49 \\
\hline 17 & $\mathrm{Bu} L(1)$ & $0.27^{*}$ & 25.79 & 2.44 & 10.83 & 1.70 & 8.93 \\
\hline 18 & $\mathrm{Bu} \cup(1)$ & N.D. & N.D. & 4.34 & 4.77 & 2.97 & 12.33 \\
\hline 19 & $\mathrm{Bu} L(2)$ & $0.21^{*}$ & 42.41 & 2.35 & 6.79 & 1.48 & 3.03 \\
\hline 20 & $\mathrm{Bu} \cup(2)$ & N.D. & N.D. & 2.41 & 4.66 & 1.48 & 0.82 \\
\hline 21 & Bu off $L$ & N.D. & N.D. & 6.46 & 6.36 & 4.64 & 3.25 \\
\hline 22 & Bu off $U$ & N.D. & N.D. & 8.14 & 4.15 & 5.84 & 1.49 \\
\hline 23 & O SA U & $0.08^{*}$ & 37.92 & 8.20 & 2.10 & 6.77 & 1.09 \\
\hline 24 & $\mathrm{O} \mathrm{Iz} \mathrm{U}$ & N.D. & N.D. & 8.41 & 11.99 & 6.22 & 6.99 \\
\hline 25 & Commercial cigarette & N.D. & N.D. & 7.17 & 5.73 & 4.47 & 2.08 \\
\hline 26 & 3R4F cigarette & N.D. & N.D. & 6.12 & 8.75 & 4.04 & 4.96 \\
\hline
\end{tabular}

${ }^{*}$ Note: Level below the lowest standard. ${ }^{* *}$ Note: N.D. $=$ not detected 


\section{REFERENCES}

1. Moldoveanu, S.C. and V. David: Sample Preparation in Chromatography; Elsevier, Amsterdam, The Netherlands, 2002. ISBN: 9780444503947

2. Court, W.A. and J. G. Hendel: Determination of NonVolatile Organic and Fatty Acids in Flue-Cured Tobacco by Gas-Liquid Chromatography; J. Chromatogr. Sci. 16 (1978) 314-317.

DOI: $10.1093 /$ chromsci/16.7.314

3. Chen, L., B. De Borba, and J. Rohrer: Determination of Organic Acids in Fruit Juices and Wines by HighPressure IC; Dionex, Application Note 1068, 2013. Available at: https://tools.thermofisher.com/content/ sfs/brochures/AN-1068-IC-Organic-Acids-Fruit-Juic e-Wine-AN70753-EN.pdf (accessed February 2018)

4. Mato, I., S. Suárez-Luque, and J. F. Huidobro: A Review of the Analytical Methods to Determine Organic Acids in Grape Juices and Wines; Food Res. Int. 38 (2005) 1175-1188.

DOI: 10.1016/j.foodres.2005.04.007

5. Hajós, P. and L. Nagy: Retention Behaviors and Separation of Carboxylic Acids by Ion-Exchange Chromatography; J. Chromatogr. B 717 (1998) 27-38.

DOI: $10.1016 / \mathrm{S} 0378-4347(98) 00247-3$

6. Masson, P.: Influence of Organic Solvents in the Mobile Phase on the Determination of Carboxylic Acids and Inorganic Anions in Grape Juice by Ion Chromatography; J. Chromatogr. A 881 (2000) 387394. DOI: 10.1016/S0021-9673(00)00164-3

7. Geng, X., S. Zhang, Q. Wang, and Z. (K.) Zhao: Determination of Organic Acids in the Presence of Inorganic Anions by Ion Chromatography With Suppressed Conductivity Detection; J. Chromatogr. A 1192 (2008) 187-190. DOI: 10.1016/j.chroma.2008.03.073

8. Bylund, D., S.H. Norström, S.A. Essén, and U.S. Lundström: Analysis of Low Molecular Mass Organic Acids in Natural Waters by Ion Exclusion Chromatography Tandem Mass Spectrometry; J. Chromatogr. A 1176 (2007) 89-93.

DOI: 10.1016/j.chroma.2007.10.064

9. Yamamoto, A., A. Yasuhara, S. Kodama, A. Matsunaga, S. Suzuki, S. Mohri, and M. Yamada: Determination of Volatile Fatty Acids in Landfill Leachates by Ion-Exclusion Chromatography; J. Sep. Sci. 27 (2004) 325-329. DOI: 10.1002/jssc. 200301679

10. Marrubini, G., A. Pedrali, P. Hemström, T. Jonsson, P. Appelblad, and G. Massolini: Column Comparison and Method Development for the Analysis of Short-Chain Carboxylic Acids by Zwitterionic Hydrophilic Interaction Liquid Chromatography With UV Detection; J. Sep. Sci. 36 (2013) 3493-3502. DOI: $10.1002 /$ jssc. 201300551

11. Nováková, L., D. Solichová, S. Pavlovičová, and P. Solich: Hydrophilic Interaction Liquid Chromatography Method for the Determination of Ascorbic Acid; J. Sep. Sci. 31 (2008) 1634-1644. DOI: $10.1002 /$ jssc. 201300551
12. Käkölä, J. and R. Alén: A Fast Method for Determining Low-Molecular-Mass Aliphatic Carboxylic Acids by High-Performance Liquid Chromatography-Atmospheric Pressure Chemical Ionization Mass Spectrometry; J. Sep. Sci. 29 (2006) 1996-2003. DOI: $10.1002 /$ jssc. 200600106

13. Zamanova, M.K., V.N. Glotova, T.N. Izhenbina, D.S. Krutas, and V.T. Novikov: Simultaneous HPLC-UV Determination of Lactic Acid, Glycolic Acid, Glycolide, Lactide and Ethyl Acetate in Monomers for Producing, Biodegradable Polymers; Procedia Chem. 10 (2014) 244-251.

DOI: $10.1016 /$ j.proche.2014.10.041

14. Gritti, F. and G. Guiochon: Comparison Between the Intra-Particle Diffusivity in the Hydrophilic Interaction Chromatography and Reversed Phase Liquid Chromatography Modes. Impact on the Column Efficiency; J. Chromatogr. A 1297 (2013) 85-95. DOI: $10.1016 /$ j.chroma.2013.04.055

15. http://www.phenomenex.com/Application/Detail/14270

16. Rose, N.: Tobacco Moisture, Water and Oven Volatiles; CORESTA Physical Test Methods Sub Group, Technical Report, July 2014. Available at: https://www.coresta.org/sites/default/files/technical documents/main/PTM-CTR_MoistureWaterOvenVola tiles_July2014\%282\%29.pdf(accessed February 2018)

17. Alford, E.D. and J.H. Lauterbach: $41^{\text {st }}$ Tobacco Chemist's Research Conference, Program, Vol. 41, No. 56, 1987, p. 41.

18. Burch T.H., J.H. Lauterbach, and S.C. Moldoveanu: $44^{\text {th }}$ Tobacco Chemist's Research Conference, Program, Vol. 44, No. 15, 1990, p.18.

19. Moldoveanu, S.C.: The Utilization of Gas Chromatography/Mass Spectrometry in the Profiling of Several Antioxidants in Botanicals; in: Advances in Gas Chromatography, edited by Guo X., Intech, Rijeka, Croatia, 2014. Available at: https://www.intechopen. com/books/advances-in-gas-chromatography/ the-utilization-of-gas-chromatography-mass-spectrometry-in-the-profiling-of-several-antioxidants-in(accessed February 2018)

20. Moldoveanu, S.C. and V. David: Essentials in Modern HPLC Separations; Elsevier, Amsterdam, The Netherlands, 2013. ISBN: 9780123850133

\section{Corresponding author}

Serban C. Moldoveanu

R.J. Reynolds Tobacco Co.

950 Reynolds Blvd.

Winston-Salem, NC 27105

USA

E-mail:modovs@rjrt.com 